\title{
Productivity of Pigeon pea (Cajanus cajan L.) Under Different Row Spacing and Genotypes
}

\author{
Kuljit Kaur* and K.S. Saini
}

Department of Agronomy, Punjab Agricultural University, Ludhiana-141004, India

*Corresponding author

A B S T R A C T

\begin{tabular}{|c|}
\hline Keywords \\
\hline $\begin{array}{l}\text { Row spacing, } \\
\text { Genotype, Yield } \\
\text { Attributes, Yield. }\end{array}$ \\
\hline Article Info \\
\hline $\begin{array}{l}\text { Accepted: } \\
10 \text { April } 2018 \\
\text { Available Online: } \\
10 \text { May } 2018\end{array}$ \\
\hline
\end{tabular}

An experiment was carried out during kharif season 2015 at Student's research farm, Punjab Agricultural University, Ludhiana on a loamy sand soil under irrigated conditions. The research is conducted to evaluate the "Productivity of Pigeon pea (Cajanus cajan L.) under Different Row Spacing and Genotypes". The field experiment was laid out in factorial randomized block design (RBD) with four replications. The treatment consisted of five planting geometries viz. $45 \mathrm{~cm} \mathrm{x} 28 \mathrm{~cm}, 50 \mathrm{~cm}$ x $25 \mathrm{~cm}, 60 \mathrm{~cm}$ x $21 \mathrm{~cm}, 75 \mathrm{~cm}$ x $17 \mathrm{~cm}$ and $90 \mathrm{~cm} \times 14 \mathrm{~cm}$ with two genotypes viz. PAU 881 (indeterminate) and AL 15 (determinate). Among the planting geometries, wider planting geometry of $60 \mathrm{~cm} \times 21 \mathrm{~cm}$ and AL 15 recorded significantly better yield attributes as compared to other treatments. The treatment combination of $60 \mathrm{~cm} \mathrm{x} 21 \mathrm{~cm}\left(14.92 \mathrm{q} \mathrm{ha}^{-1}\right)$ and AL 15 (13.24 q ha $\left.{ }^{-1}\right)$ was significantly higher seed yield.

\section{Introduction}

Pulses form an integral part of vegetarian diet in Indian subcontinent. India is the major pulse growing country, accounting for about one third of the total world area under pulses and one-fourth of the world production of pulses. Certain unique features of pulses viz., their ability to fix atmospheric nitrogen in symbiotic association with rhizobium, deep penetrating root system enabling them to draw moisture from deeper moist soil layers and high seed protein content ranging from 20 to $30 \%$ makes them indispensable (Selvi et al., 2009). The area under pulses is not enough to meet the requirement of per capita availability of pulses. It has led to the severe shortage of pulses in India, which has aggravated the problem of malnutrition in large section of vegetarian population. Therefore, there is a great need for attentive measures against pulses i.e. increase the production of pulses. Pigeon pea is the major kharif pulse crop of India and comes second after chickpea. Thus, there is a good scope of increasing productivity of pigeon pea through different agronomic manipulations (Mallikarjun et al., 2014).

The combination of row spacing with respect to genotype may have a big deal from production point of view. Proper row spacing arrangement helps in efficient utilization of resources and genotype plays an important role in determining the crop yields. 


\section{Materials and Methods}

A field experiment was conducted at the Student's Research Farm of the Punjab Agricultural University, Ludhiana, Punjab, during kharif 2015. The soil of the experimental plot was sandy loam with irrigated conditions having normal $\mathrm{pH}$ (7.2), low in organic carbon $(0.26 \%)$ and available nitrogen $\left(81.5 \mathrm{~kg} \mathrm{ha}^{-1}\right)$, medium in available phosphorus $\left(17.5 \mathrm{~kg} \mathrm{ha}^{-1}\right)$, low in available potassium $\left(103.0 \mathrm{~kg} \mathrm{ha}^{-1}\right)$.

The experiment consisted of ten treatment combinations, comprising of five row spacings; $(45 \mathrm{~cm} \times 28 \mathrm{~cm}),(50 \mathrm{~cm} \times 25 \mathrm{~cm})$, $(60 \mathrm{~cm} \times 21 \mathrm{~cm}),(75 \mathrm{~cm} \times 17 \mathrm{~cm})$ and $(90 \mathrm{~cm}$ $\mathrm{x} 14 \mathrm{~cm}$ ) which were allotted with two genotypes viz. PAU 881 (indeterminate) and AL 15 (determinate) and were laid out in factorial randomized block design (RBD) with four replications. Five plants were tagged at random in net plot area for recording various yield components. The crop was sown and harvested at recommended date of sowing and harvesting. At the end, threshing operations were performed manually. The seed yield of every net plot was put in separate bags with specific tags. The data on various yield and yield parameters were statistically analysed by using CPCS1, software developed by Department of Statistics, Punjab Agricultural University, Ludhiana based on the procedure of Cochran and Cox (1967).

\section{Results and Discussion}

\section{Pods plant $^{-1}$}

The data given in table 1 depicted the number of pods plant ${ }^{-1}$ i.e. an important primary yield component, was affected significantly by different row spacing and ranged from 147.6 to 142.5. Maximum average pods plant ${ }^{-1}$ (147.6) were recorded in $60 \mathrm{~cm}$ row spacing followed by $50 \mathrm{~cm}$ row spacing with 145.3 pods plant ${ }^{-1}$ while the lowest number of pods (142.5) were recorded in $90 \mathrm{~cm}$ row spacing. The AL 15 genotype had significantly higher number of pods than PAU 881. The interactional effect of both treatments i.e. row spacing and genotypes remained nonsignificant.

\section{Seeds pods ${ }^{-1}$}

Number of seeds pod $^{-1}$ is considered an important factor that directly imparts an exploiting potential recovery in leguminous crops. The data regarding number of seeds per pod given in table 1 showed that it was significantly affected by row spacing. Maximum number of seeds per pod (4.8) were recorded in $60 \mathrm{~cm}$ row spacing followed by 50 $\mathrm{cm}$ row spacing $\left(4.5\right.$ seeds pod $\left.{ }^{-1}\right)$ and $45 \mathrm{~cm}$ row spacing $\left(4.3\right.$ seeds pod $\left.{ }^{-1}\right)$, but $50 \mathrm{~cm}$ and $45 \mathrm{~cm}$ row spacing also statistically at par with $60 \mathrm{~cm}$. while the minimum number of seeds pod $^{-1}$ (3.9) were recorded in $90 \mathrm{~cm}$ row spacing. Among the genotypes, AL 15 had more number of seeds pod $^{-1}$ than PAU 881, but both genotypes become statistically nonsignificant.

\section{Pod length (cm)}

The data on pod length presented in table 1 revealed that the row spacing and genotypes had significant effect on the pod length. The $60 \mathrm{~cm}$ row spacing had higher pod length than $45 \mathrm{~cm}, 50 \mathrm{~cm}, 75 \mathrm{~cm}$ and $90 \mathrm{~cm}$, but it was at par with $45 \mathrm{~cm}$ and $50 \mathrm{~cm}$. The genotypes $\mathrm{AL}$ 15 and PAU 881 had non-significant results in pod length. The less pod length due to less vegetation which would be decreased the photosynthetic assimilation from source to sink.

\section{0 seed weight $(g)$}

Among various parameters contributing towards final yield of a crop, 100 seed weight 
is of prime importance. Data given in table 1 showed that different row spacing significantly affected the 100 seed weight $(\mathrm{g})$. Maximum average 100 seed weight $(8.9 \mathrm{~g})$ was recorded in $60 \mathrm{~cm}$ row spacing followed by $50 \mathrm{~cm}(7.2 \mathrm{~g}), 45 \mathrm{~cm}(6.4 \mathrm{~g}), 75 \mathrm{~cm}(5.7 \mathrm{~g})$ and $90 \mathrm{~cm}$ with 100 seed weight of $5.4 \mathrm{~g}$. While the $50 \mathrm{~cm}$ and $45 \mathrm{~cm}$ row spacings were recorded 100 seed weight at par with $60 \mathrm{~cm}$ row spacing.

Among the genotypes, AL 15 (7.3) genotype was significantly higher than treatment of PAU 881 (7.6).

The maximum 100-seed weight of genotype AL 15 than PAU 881was due to its higher efficiency in translocations of the photosynthates to the reproductive parts. Similar findings have been reported by (Chandrakar et al., 2015).

\section{Yield}

\section{Seed yield}

Seed yield is the function of pods length, number of pods per plant, seeds per pod and seed weight. The data showed that seed yield varied significantly due to different row spacing (Table 2). $60 \mathrm{~cm}$ row spacing $(14.92 \mathrm{q}$ $\mathrm{ha}^{-1}$ ) produced the significantly higher seed yield than $45 \mathrm{~cm}\left(12.86 \mathrm{q} \mathrm{ha}^{-1}\right), 50 \mathrm{~cm}(13.24$ $\left.\mathrm{q} \mathrm{ha}^{-1}\right), 75 \mathrm{~cm}\left(12.06 \mathrm{q} \mathrm{ha}^{-1}\right)$ and $90 \mathrm{~cm}(11.07$ $\left.\mathrm{q} \mathrm{ha}{ }^{-1}\right)$. The higher seed yield in $60 \mathrm{~cm}$ row spacing than other row spacing of $45 \mathrm{~cm}, 50$ $\mathrm{cm}, 75 \mathrm{~cm}$ and $90 \mathrm{~cm}$. Similarly, determinate genotype AL 15 resulted more yield than the indeterminate genotype PAU 881 due to uniform growth behavior during vegetative and reproductive phase of pigeon pea. Similar results were found by Mula et al., (2013) (Fig. $1)$.

Table.1 Yield attributes as influenced by different row spacing and genotypes of pigeon pea

\begin{tabular}{|c|c|c|c|c|}
\hline Treatment & $\begin{array}{l}\text { Pods per plant } \\
\text { (no.) }\end{array}$ & Pod length $(\mathrm{cm})$ & $\begin{array}{l}\text { Seeds per pod } \\
\text { (no.) }\end{array}$ & $\begin{array}{l}\text { 100-seed weight } \\
\text { (g) }\end{array}$ \\
\hline \multicolumn{5}{|c|}{ Row spacing $(\mathbf{c m})$} \\
\hline $\begin{array}{llll}\begin{array}{lll}45 \\
\mathrm{~cm}\end{array} & \mathrm{~cm} & \mathrm{x} & 28 \\
\end{array}$ & 145.0 & 3.9 & 4.4 & 6.8 \\
\hline $50 \mathrm{~cm} \times 25 \mathrm{~cm}$ & 145.3 & 4.3 & 4.5 & 7.2 \\
\hline $\begin{array}{llll}60 & \mathrm{~cm} & \mathrm{x} & 21 \\
\mathrm{~cm} & & & \\
\end{array}$ & 147.6 & 4.6 & 4.8 & 8.9 \\
\hline $\begin{array}{llll}75 & \mathrm{~cm} & \times & 17 \\
\mathrm{~cm}\end{array}$ & 143.1 & 3.5 & 4.0 & 5.7 \\
\hline $\begin{array}{llll}90 & \mathrm{~cm} & \mathrm{x} & 14 \\
\mathrm{~cm}\end{array}$ & 142.5 & 3.4 & 3.9 & 5.4 \\
\hline $\mathrm{SEm} \pm$ & 1.6 & 0.2 & 0.1 & 0.2 \\
\hline $\mathrm{CD}(\mathrm{p}=0.05)$ & 2.2 & 0.8 & 0.5 & 0.6 \\
\hline \multicolumn{5}{|l|}{ Genotypes } \\
\hline PAU 881 & 141.1 & 3.9 & 4.2 & 6.3 \\
\hline AL 15 & 147.7 & 4.0 & 4.4 & 7.3 \\
\hline SEm \pm & 1.0 & 0.1 & 0.09 & 0.1 \\
\hline $\mathrm{CD}(\mathrm{p}=0.05)$ & 5.86 & NS & NS & 0.4 \\
\hline Interaction & NS & NS & NS & NS \\
\hline
\end{tabular}


Table.2 Effect of different row spacing and genotypes on seed yield, stover yield, and biological yield and harvest index of pigeon pea

\begin{tabular}{|c|c|c|c|c|}
\hline Treatment & $\begin{array}{l}\text { Seed yield } \\
\left(\mathbf{q} \mathbf{h a}^{-1}\right)\end{array}$ & $\begin{array}{l}\text { Stover yield } \\
\qquad\left(\mathrm{q} \mathrm{ha}^{-1}\right)\end{array}$ & $\begin{array}{l}\text { Biological yield } \\
\qquad\left(\mathrm{q} \mathbf{h a}^{-1}\right)\end{array}$ & $\begin{array}{c}\text { Harvest Index } \\
(\%)\end{array}$ \\
\hline \multicolumn{5}{|c|}{ Row spacing (cm) } \\
\hline $45 \mathrm{~cm} \times 28 \mathrm{~cm}$ & 12.86 & 41.54 & 54.40 & 23.64 \\
\hline $50 \mathrm{~cm} \times 25 \mathrm{~cm}$ & 13.24 & 42.23 & 55.47 & 23.87 \\
\hline $60 \mathrm{~cm} \times 21 \mathrm{~cm}$ & 14.92 & 44.41 & 59.33 & 25.14 \\
\hline $75 \mathrm{~cm} \times 17 \mathrm{~cm}$ & 12.06 & 41.31 & 53.37 & 22.60 \\
\hline $90 \mathrm{~cm} \times 14 \mathrm{~cm}$ & 11.07 & 40.39 & 51.46 & 21.52 \\
\hline $\operatorname{SEm} \pm$ & 0.4 & 0.3 & 0.7 & 1.9 \\
\hline $\mathrm{CD}(\mathrm{p}=0.05)$ & 1.23 & 1.14 & 2.18 & NS \\
\hline \multicolumn{5}{|l|}{ Genotypes } \\
\hline PAU 881 & 12.42 & 41.33 & 53.75 & 23.1 \\
\hline AL 15 & 13.24 & 42.62 & 55.86 & 23.7 \\
\hline$\overline{S E m} \pm$ & 0.2 & 0.2 & 0.5 & 1.2 \\
\hline CD $(p=0.05)$ & 0.78 & 0.72 & 1.37 & NS \\
\hline Interaction & NS & NS & NS & NS \\
\hline
\end{tabular}

Variable Cost- (18,982 Rs. ha $\left.{ }^{-1}\right)$

Fig.1 Response of different yield attributes under different row spacing and genotypes of pigeon pea

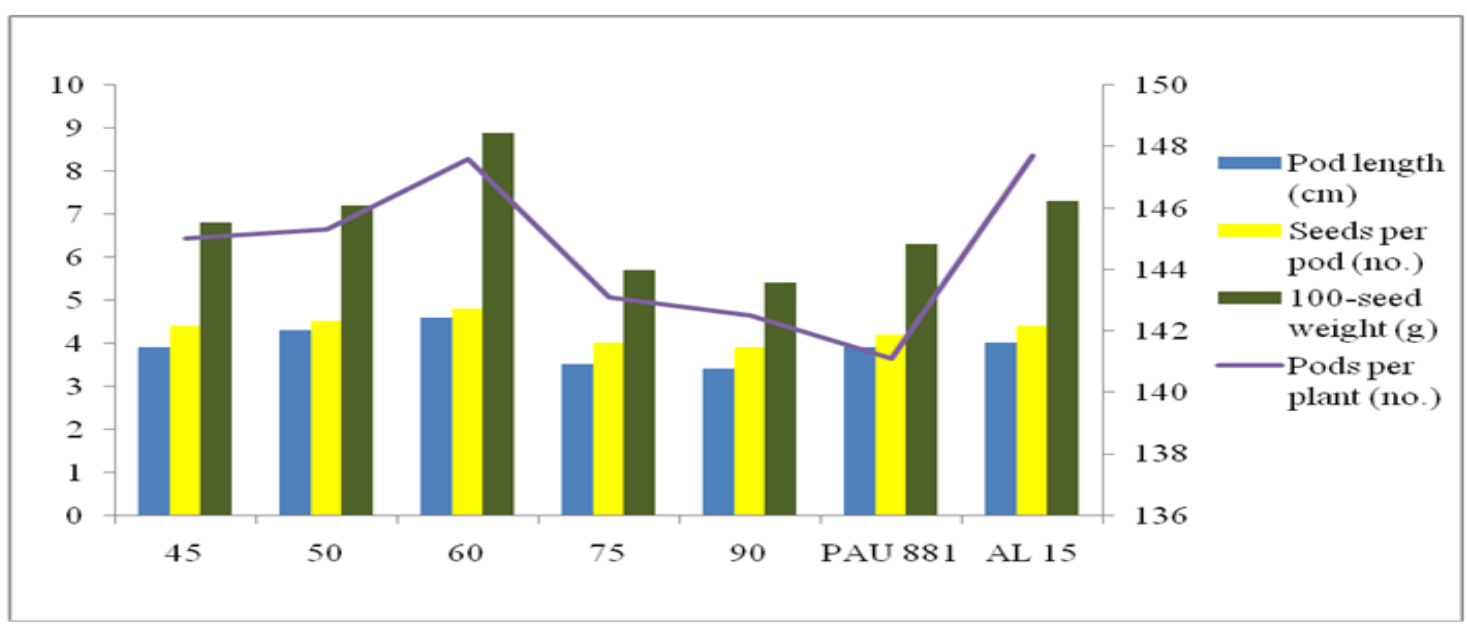

\section{Stover yield}

The superiority of growth characters like plant height, branches, LAI and dry matter accumulation may be the possible reasons for the production of higher stover yield. Among the planting geometry, significantly higher stover yield was recorded from the $60 \mathrm{~cm}$ (44.41q ha ${ }^{-1}$ ) planting geometry, while the lowest stover yield (40.39 $\left.\mathrm{q} \quad \mathrm{ha}^{-1}\right)$ was recorded in wider spacing $90 \mathrm{~cm}$ planting geometry. Similar results have also been reported by Worku and Demisie (2012). Similarly, due to better and uniform plant stand and growth habits of determinate genotype AL 15 resulted significantly higher 
stover yield than indeterminate genotype PAU 881.

\section{Biological yield}

Biological yield is sum total of all dry matter produced through physiological and biochemical processes occurring in the plant system.

Data given in table 2 shows the effect of different row spacings and genotypes on biological yield. Among the different row spacings $\quad 60 \mathrm{~cm} \quad\left(59.33 \quad \mathrm{q} \quad \mathrm{ha}^{-1}\right) \quad$ had significantly higher biological yield than 50 $\mathrm{cm}\left(55.47 \mathrm{q} \mathrm{ha}^{-1}\right), 45 \mathrm{~cm}\left(54.40 \mathrm{q} \mathrm{ha}^{-1}\right), 75 \mathrm{~cm}$ $\left(53.37 \mathrm{q} \mathrm{ha}^{-1}\right)$ and $90 \mathrm{~cm}\left(\mathrm{q} \mathrm{ha}^{-1}\right)$. The AL 15 $\left(55.86 \mathrm{q} \mathrm{ha}^{-1}\right)$ performed significantly better than PAU $881\left(53.75 \mathrm{q} \mathrm{ha}^{-1}\right)$.

\section{Harvest index}

Harvest index is a measure of physiological productivity potential of crop genotypes. It is the ability of a plant to convert the dry matter into economic yield. The difference in harvest index percentage genotypes was found to be non-significant. The highest value of harvest index $(25.14 \%)$ was recorded under $60 \mathrm{~cm}$ planting geometry and the minimum harvest index percentage was found in $90 \mathrm{~cm}$ row spacing. This might be low due to less dry matter accumulation, number of seed pod $^{-1}$ and 100-seed weight.

\section{Acknowledgments}

The authors are heartily thankful to Department of Agronomy, College of Agriculture, PAU (Ludhiana) for providing student's field trial facilities and also thankful to my adviser, PAU (Ludhiana) for providing the facilities for the investigation.

\section{References}

Chandrakar K, Chandrakar D K, Das G K and Birendra T 2015. Climate resilient agro technological intervention to boost up pigeon pea production in Chhattisgarh. Journal of Environmental Science Toxicology and Food Technology 1: 48-52

Cochran W G and Cox G M 1967. Experiment Designs. Asia publishing House, New Delhi, India.

Mallikarjun C, Hulihalli U K, Somanagouda G, Kubsad V S and Kambrekar 2014. Performance of hybrid pigeon pea (cv. ICPH-2671) under varied planting methods and planting geometries in Northern dry zone of Karnataka. Karnataka Journal of Agricultural Science 27: 296-99

Mula M G, Saxena K B, Rathore A and Kumar R V2013. Effect of row ratio, spacing, and irrigation on seed production of a hybrid parent line ICPA 2043 (CMS) of pigeon pea. Green Farming4: 262-66

Selvi R V, Srinivasan S, Ramasamy M and Marimuthu R 2009. Agronomic management for pigeon pea under drought conditions. Legume Research 32: $139-41$

Worku W and Demisie W 2012. Growth, light interception and radiation use efficiency response of pigeon pea (Cajanus cajan) to planting density in Southern Ethiopia. AgronomyJournal 11: 85-93.

\section{How to cite this article:}

Kuljit Kaur and Saini, K.S. 2018. Productivity of Pigeon pea (Cajanus cajan L.) Under Different Row Spacing and Genotypes. Int.J.Curr.Microbiol.App.Sci. 7(05): 942-946. doi: https://doi.org/10.20546/ijcmas.2018.705.116 